\title{
Травма грудної клітки: особливості перебігу, ускладнення та лікувальна тактика
}

\begin{abstract}
Мета роботи: узагальнити досвід лікування хворих з ускладненою травмою грудної клітки.
На базі відділення торакальної хірургії КНП “Тернопільська університетська лікарня” ТОР за період 2015-2019 рр. проліковано 447 хворих із торакальною травмою.

У 185 пацієнтів проведено металоостеосинтез (MOC) ребер LCP, що сприяє ранній мобілізації пацієнтів, забезпечуючи стійку фіксацію уламків та зменшення больового синдрому. Торакотомію виконано у 198 (44,3 \%) пацієнтів, VATS було успішно проведено у 19 (4,3 \%) пацієнтів. Проведені втручання полягали в ліквідації згорнутого гемотораксу, гемостазі при внутрішньоплевральних кровотечах, ушиванні розривів діафрагми, резекціях легень при наявності масивних розривів чи пневмоцеле. Поранення серця є одним із найтяжчих при лікуванні проникаючих поранень грудної клітки. За наявності рани в зоні Грекова проводилась екстрена торакотомія з ушиванням рани серця, реінфузією крові та зашиваням перикарда вузловими рідкими швами з накладанням контрапертури.
\end{abstract}

Ключові слова: травма грудної клітки; ускладнення; управління.

Зростання транспортного, побутового та виробничого травматизму призвело до того, що механічна травма в економічно розвитих регіонах сьогодні $є$ головною причиною смертності та інвалідності чоловіків працездатного віку. При лікуванні 25 \% стаціонарних пацієнтів 3 торакальною травмою допускаються серйозні діагностичні й тактичні помилки, а у 30 \% поєднані пошкодження стають безпосередньою причиною смерті [1, 2]. Закриті травми грудної клітки (ЗТГК) з множинними або флотуючими переломами ребер у 80-90 \% випадків супроводжуються внутрішньоплевральними ускладненнями через травми міжреберних судин та поранення легень [3, 4].

Мета роботи: узагальнити досвід лікування хворих з ускладненою травмою грудної клітки.

На базі відділення торакальної хірургії КНП “Тернопільська університетська лікарня” ТОР за період 2015-2019 рр. проліковано 447 хворих віком від 19 до 84 років, середній їх вік склав 48,4 року. Розподіл пацієнтів за статтю був наступним - 168 жінок та 279 чоловіків. Ці дані пояснюються переважанням у структурі травматизму пошкоджень під час ДТП, падіння з висоти, виробничих травм.

Розглядаючи терміни надходження хворих до стаціонару, слід зазначити, що в строки до однієї години після травми в клініку надійшли 82 хворих (18,3 \%), до 24 годин - 226 (50,5 \%) хворих, від 1 до 14 діб - 139 (31 \%) хворих. Проникаючі поранення грудної клітки були виявлені у 134 пацієнтів (31 \%), закрита травма - у 313 (69 \%). Перелом 1-3 ребер зафіксовано у 177 постраждалих
(39,6 \%), 3-4 ребер - у 158 (35,4 \%), 5 та більше ребер - у 112 (25-\%). У 62 випадках (13,8 \%) виявлено двобічні переломи ребер, у 32 (7,8 \%) - флотуючий сегмент. Внутрішньоплевральні ускладнення діагностовані у 342 пацієнтів (76,6 \%), у тому числі з пораненнями серця і перикарда - в 29 пацієнтів (6,5\%).

У приймальному відділенні всім постраждалим виконано рентгенографію органів грудної клітки, електрокардіографію, загальний аналіз крові та сечі, коагулограму, сонографічне дослідження органів черевної порожнини [5]. Найінформативнішим методом діагностики $\epsilon$ комп'ютерна томографія, яку виконували при поступленні всім пацієнтам. Поряд із цим, пацієнти консультовані лікарями суміжних фахів. При наявності показань їм проводили санаційну та діагностичну бронхоскопію, торакоскопічну ревізію органів плевральної порожнини з наступним iї дренуванням за Бюлау.

Порушення біомеханіки дихання та внутрішньолегеневого газообміну найбільше виражені при численних переломах ребер та наявності флотуючого сегмента, складних переломах груднини. Фіксація цих дефектів $є$ одним із патогенетичних заходів у комплексі надання хірургічної допомоги постраждалим. У 185 пацієнтів проведено металоостеосинтез (МОС) ребер за допомогою блокованих компресуючих пластин (LCP). Ця методика сприяє ранній мобілізацію пацієнтів, забезпечє стійку фіксацію уламків в умовах постійної рухомості грудної клітки. Відновлення каркасності суттєво зменшує больовий синдром, покращує біоме- 
ханіку дихання, зменшує кількість післяопераційних ускладнень. Контроль над болем та мобілізація грудної клітки $є$ відправними точками у лікуванні ізольованої травми грудної клітки. При наявності внутрішньоплевральних ускладнень операція доповнювалася ревізією плевральної порожнини. Торакотомію виконано у 198 (44,3 \%) пацієнтів, VATS було успішно проведено у 19 (4,3 \%) пацієнтів. Показанням для торакоскопії був малий та середній гемоторакс, підозра на ушкодження діафрагми, травму серця, внутрішньоплевральні чужорідні тіла, пневмоторакс з наявністю пошкодження легені та нориці, що функціонує [6]. Проведені втручання полягали в ліквідації згорнутого гемотораксу, гемостазі при внутрішньоплевральних кровотечах, ушиванні розривів діафрагми, резекції легень при наявності масивних розривів чи пневмоцеле. Протипоказаннями до застосування ВАТС, як основного методу лікування, вважали середній гемоторакс із кровотечею, що продовжується, великий гемоторакс, великі відкриті рани грудної клітки, пошкодження трахеї, бронхів та вкрай високий анестезіологічний ризик. Наявність великого гемотораксу свідчить про ушкодження судини великого калібру, тому використання ВАТС супроводжується поганою візуалізацією та значним збільшенням тривалості операції. Це, в свою чергу, призводить до великої крововтрати, що може створювати пряму загрозу життю пацієнта.

Поранення серця $є$ одним із найскладніших у лікуванні проникаючих поранень грудної клітки. 329 пацієнтів з пораненнями серця і перикарда проникаючі рани камер серця діагностовано у 7 випадках, непроникаючі - у 10; пошкодження перикарда - у 12. За наявності рани в зоні Грекова переконливо визначались прояви гострої тампо-

\section{СПИСОК ЛІТЕРАТУРИ}

1. Шейко В. Д. Хирургия повреждений при политравме мирного и военного времени / В. Д. Шейко. - Полтава : ООО “АСМИ”, 2015. - 557 с.

2. Келемен I. Я. Множинні переломи ребер при закритій травмі грудної клітки. Хірургічна тактика / І. Я. Келемен, М. М. Савула, В. С. Дідик // Науковий вісник Ужгородського університету. - 2011. - № 40. - С. 72-79.

3. Асланян С. А. Поранення перикарду / С. А. Асланян, О. В. Воробей, Ф. М. Новіков [та ін.] // Таврический медико-биологический вестник. - 2011. - Т. 14, № 4, ч. 1 (56). - С. 11-13. нади серця (ціаноз обличчя та верхніх відділів тулуба, пульсація вен шиї), тріади Бека (різке зниження артеріального тиску, значне підвищення центрального венозного тиску, різке послаблення серцевих тонів). Операційний доступ був стандартний - лівобічна передньобокова торакотомія в 5-6 міжребер'ї. Після розкриття перикарда попереду n. phrenicus проводили ревізію його порожнини та поверхні міокарда. При вираженій гіпотензії та зупинці серця здійснювали тимчасову зупинку кровотечі шляхом тампонади рани з подальшим її ушиванням атравматичним шовним матеріалом. У випадках зупинки серцевої діяльності проводили прямий масаж серця та дефібриляцію, паралельно - реінфузію крові та інтенсивну інфузійну терапію. Після ушивання рани серця в порожнину перикарда встановлювали тонкий дренаж, а сам перикард зашивали вузловими рідкими швами з накладанням контрапертури.

Висновки. Металоостеосинтез ребер LCP при множинних флотуючих переломах ребер з порушенням каркасності грудної стінки, преломах ребер зі зміщенням уламків у пацієнтів працездатного віку, з внутрішньоплевральними ускладненнями, вираженим больовим синдромом та дихальними розладами є сучасним високотехнологічним, функціональним і малотравматичним методом лікування.

Використання відеоасистованої торакоскопії є операцією вибору при хірургічному лікуванні хворих із травмами органів грудної клітки за умов стабільної гемодинаміки. Цей метод має високу діагностичну цінність, супроводжується мінімальною травматичністю.

Наявність проникаючих ран у зоні Грекова в пацієнтів із нестабільною гемодинамікою $є$ показанням до реанімаційного оперативного втручання.

4. Cohn S. M. Pulmonary contusion: an Update on Recent Advances in Clinical Management / S. M. Cohn, J. P. Du Bose // World J. Surg. - 2010. - No. 34. -P. 1959-1970.

5. Richards J. R. Focused Assessment with Sonography in Trauma (FAST) in 2017: What Radiologists Can Learn / J. R. Richards, J. P. Mc Gahan // Radiology. - 2017. - No. 1 (283). - P. 31-48

6. Fabbrucci P. Video-assisted thoracoscopy in the early diagnosis and management of post-traumatic pneumothorax and hemothorax / P. Fabbrucci, L. Nocentini, S. Secci // Surg. Endosc. 2008. - No. 22. - P. 1227-1231. 


\section{REFERENCES}

1. Kelemen, I.Ya., Savula, M.M., \& Didyk, V.S. (2011). Mnozhynni perelomy reber pry zakrytii travmi hrudnoi klitky. Khirurhichna taktyka [Multiple fractures of ribs with closed chest injury. Surgical tactics]. Naukovyi visnyk Uzhhorodskoho universytetu - Scientific Bulletin of Uzhhorod University, 40, 7279 [in Ukrainian].

2. Sheyko, V.D. (2015). Khirurgiya povrezhdeniy pri politravme mirnogo i voennogo vremeni [Damage surgery for political trauma in peace and war]. Poltava: OOO "ASMY” [in Russian]. 3. Aslanian, S.A., Vorobei, O.V., Novikov, F.M., Vorobei, I.O., Dopiriak, O.V., Rybitskyi, H.A., \& Aslanian L.S. (2011). Poranennia perykardu [Pericardial injuries]. Tavricheskyy medyko-biologicheskyy vestnyk - Taurian Medico-Biological Bulletin, 4 (56), 11-13 [in Ukrainian].

4. Cohn, S.M, Du Bose, J.P. 2010. Pulmonary contusion: an Update on Recent Advances in Clinical Management. World J. Surg. 34, 1959-1970.

5. Richards, J.R., \& Mc Gahan, J.P. (2017). Focused assessment with sonography in trauma (FAST) in 2017: What radiologists can learn. Radiology, 1 (283), 31-48

6. Fabbrucci, P., Nocentini, L., \& Secci, S. (2008). Videoassisted thoracoscopy in the early diagnosis and management of post-traumatic pneumothorax and hemothorax. Surg. Endosc., 22, 1227-1231.

Отримано 31.10.2019

Електронна адреса для листування: shuba.viyt@gmail.com

\section{A. D. BEDENIUK, V. V. MALOVANYY, L. E. VIYTOVYCH, I. I. DOVHA}

I. Horbachevsky Ternopil National Medical University

\section{CHEST TRAUMA: FEATURES, COMPLICATIONS, AND TREATMENT TACTICS}

The aim of the work: to summarize the experience of treating patients with complicated chest trauma. On the basis of the Department of Thoracic Surgery of Ternopil University Hospital for the period 2015-2019 was treated 447 patients with toral injury were treated.

185 patients underwent metalo-osteosynthesis (MOS) ribs with LCP, which allows for early mobilization of patients, providing stable fixation of debris, reduction of pain. Thoracotomy was performed in 198 (44.3\%) patients, VATS was successfully performed in 19 $(4.3 \%)$ patients. The interventions consisted in the elimination of convoluted hemothorax, hemostasis in intra-pleural hemorrhages, suturing of diaphragm ruptures, resections of the lungs in the presence of massive ruptures or pneumocele. Heart wounds are one of the most difficult in the treatment of penetrating chest wounds. In the presence of a wound in the Grekov area, an emergency thoracotomy was performed with suturing of the heart wound, blood reinfusion and suturing of the pericardium with nodal sutures with the imposition of a contra-perforation.

Key words: chest trauma; complications; management.

\section{А. Д. БЕДЕНЮК, В. В. МАЛЕВАНЫЙ, Л. Е. ВИЙТОВИЧ, И. И. ДОВГА}

Тернопольский национальный медицинский университет имени И. Я. Горбачевского МОз Украины

\section{ТРАВМА ГРУДНОЙ КЛЕТКИ: ОСОБЕННОСТИ ТЕЧЕНИЯ, ОС.ОЖНЕНИЯ И ЛЕЧЕБНАЯ ТАКТИКА}

Цель работы: обобщить опыт лечения больных с осложненной травмой грудной клетки.

На базе отделения торакальной хирургии КНП “Тернопольская университетская больница” ТОР за период 2015-2019 гг. пролечено 447 больных с торакальной травмой.

У 185 пациентов проведен металоостеосинтез (MOC) ребер LCP, что способствует ранней мобилизации пациентов, обеспечивая устойчивую фиксацию обломков и уменьшение болевого синдрома. Торакотомия выполнена у 198 (44,3 \%) пациентов, VATS была успешно проведена у 19 (4,3 \%) пациентов. Проведенные вмешательства заключались в ликвидации свернутого гемоторакса, гемостазе при внутриплевральных кровотечениях, ушивании разрывов диафрагмы, резекции легкого при наличии массивных разрывов или пневмоцеле. Ранения сердца являются одними из самых трудных в лечении проникающих ранений грудной клетки. При наличии раны в зоне Грекова проводилась экстренная торакотомия с ушиванием раны сердца, реинфузия крови и ушиванием перикарда узловыми редкими швами с наложением контрапертуры.

Ключевые слова: травма грудной клетки; осложнения; управление. 